\title{
Peningkatan Kompetensi Peternak dan Keberlanjutan Usaha Sapi Potong di Desa Oebkim Kecamatan Bikomi Selatan Kabupaten Timor Tengah Utara
}

Ture Simamora

${ }^{a}$ Fakultas Pertanian, Universitas Timor, Kefamenanu, TTU - NTT, Indonesia.Email: feathertures@rocketmail.com

\section{Article Info}

\section{Article history:}

Received 18 Januari 2020

Received in revised form 3 Februari 2020

Accepted 18 Februari 2020

DOI:

https://doi.org/10.32938/ag.v5i2.1007

Keywords:

Kompetens

Peternak

\begin{abstract}
Abstrak
Kompetensi merupakan hasil dari sebuah proses pemberdayaan. Pemberdayaan merupakan suatu proses yang bertujuan untuk memberikan daya-daya pada masyarakat atau kegiatan yang membuat masyarakat mampu membangun dirinya sendiri, mampu bekerjasama. Tujuan dari penelitian ini adalah untuk menganalisis karakteristik peternak, dukungan penyuluhan, dukungan lingkungan eksternal, tingkat kompetensi, tingkat keberlanjutan serta menganalisis faktor yang berpengaruh terhadap kompetensi dan keberlanjutan usaha ternak sapi potong di Desa Oebkim Kecamatan Bikomi Selatan Kabupaten Timor Tengah Utara. Hasil penelitian menunjukkan faktor yang mempengaruhi kompetensi peternak di Desa Oebkim adalah dukungan lingkungan eksternal. Kompetensi peternak direfleksikan oleh kemampuan dalam pemasaran. Kelembagaan pasar dan modal belum sepenuhnya berfungsi pada usaha peternakan sapi potong. Sebagian peternak masih kesulitan dalam mengakses modal dan kredit usaha sehingga peternak terbatas dalam menambah skala usahanya. Fak tor yang mempengaruhi keberlanjutan usaha peternakan sapi potong di Desa Oebkim adalah karakteristik peternak. Karakteristik peternak di refleksikan oleh umur dan pendidikan. Kompetensi tidak berpengaruh terhadap keberlanjutan usaha peternakan sapi potong di Desa Oebkim.
\end{abstract}

\section{Pendahuluan}

Kompetensi merupakan hasil dari sebuah proses pemberdayaan Pemberdayaan merupakan suatu proses yang bertujuan untuk memberikan daya-daya pada masyarakat atau kegiatan yang membuat masyarakat mampu membangun dirinya sendiri, mampu bekerjasama, berani menghadapi resiko, dan mampu bertindak sesuai situasi (Slamet 2003). Pemberdayaan masyarakat tidak cukup hanya dengan meningkatkan produktivitas, memberikan kesempatan berusaha yang sama tetapi juga bisa menjamin adanya kerjasama dan kemitraan yang erat antara yang telah maju dan belum berkembang.

Pada bidang peternakan kompetensi peternak menjadi penting dalam mencapai keberhasilan usaha. Peternak dalam mengelola usahanya diharapkan mampu membangun usaha dan menjalin kemitraan dengan peternak lain (Muharastri et al. 2005). Namun peternak di nilai belum mampu membangun usaha peternakan dan menjalin kerjasama dengan pihak lain dalam rangka peningkatan pendapatan. Peternak sapi potong di Indonesia pada umumnya masih beternak secara tradisional. Hal ini tercermin dari perilaku peternak dalam manajemen usahanya masih menggunakan cara - cara beternak yang diperoleh secara turun temurun.

Menurut Mauludin et al. (2012) permasalahan peternak yang belum memiliki kompetensi optimal berkaitan dengan tipe pendekatan pemberdayaan. Peternak belum kompeten berhubungan dengan arus pembangunan yang lebih menempatkan peternak sebagai obyek sehingga potensi kreatif peternak menjadi kurang berkembang. Permasalahan rendahnya produksi hasil ternak dinilai dipengarungi kompetensi peternak dalam mengakses berbagai sumberdaya. Kompetensi peternak dalam mengembangkan usaha ternak akan mempengaruhi produktivitas produk pangan hewani, kemampuan membangun dan membina kelembagaan peternakan.

Dengan demikian keberadaan kelembagaan pendukung usaha peternakan sapi potong diduga belum sepenuhnya berpihak kepada peternak. Keberadaan penyuluh yang memiliki peran penting dalam kompetensi peternak seharusnya berperan secara optimal. Kehadiran kelompok peternak sejatinya berfungsi optimal dalam menfasilitasi anggota - anggotanya untuk menjadi peternak sapi potong yang berkualitas (Hasnawati et al. 2019). Desa Oebkim Kecamatan Bikomi Selatan Kabupaten Timor Tengah Utara merupakan salah satu daerah peternakan. Sebagian besar peternak di daerah tersebut adalah peternak sapi potong tipe pedaging skala rakyat. Peternak memelihara ternak sapi potong secara individu. Berdasarkan Data Desa Oebkim jumlah peternak sapi potong di desa tersebut berjumlah 33 orang.

Dengan demikian perlu penelitian penyebab para peternak masih dalam keadaan tidak berdaya padahal banyak kebijakan-kebijakan pembangunan yang berorientasi ke peternakan sudah sejak lama dibuat oleh pemerintah. Kajian kajian yang memfokuskan kepada penelaahan tingkat kompetensi peternak sapi potong juga belum banyak ditemukan khususnya bila dikaitkan dengan peran penyuluhan yang mempengaruhinya. Oleh karena itu, tujuan penelitian ini adalah untuk menganalisis dukungan penyuluhan, dukungan lingkungan eksternal, tingkat kompetensi serta menganalisis faktor - faktor yang berpengaruh terhadap kompetensi peternak sapi potong di Desa Oebkim.

\section{Metode}

Penelitian menggunakan paradigma kuantitatif dengan rancangan penelitian survei yang bersifat menerangkan (explanatory research). Penelitian ini dilakukan di Kecamatan Bikomi Selatan dengan mengambil lokasi di Desa Oebkim sebagai lokasi penelitian. Pemilihan Desa Oebkim sebagai lokasi penelitian disebabkan daerah tersebut merupakan salah satu kawasan usaha peternakan sapi potong. Penelitian dilakukan pada bulan Maret 2020. Populasi penelitian adalah seluruh peternak sapi potong yang ada di Desa Oebkim. Jumlah populasi dalam penelitian ini adalah 33 orang. Penelitian ini dilakukan secara sensus yaitu menjadikan seluruh anggota populasi penelitian sebagai sampel. Pertimbangan tersebut didasarkan jumlah populasi relatif kecil.

Data yang dikumpulkan dalam penelitian ini terdiri dari data primer dan data sekunder. Pengumpulan data primer dalam penelitian ini menggunakan kuisioner yang bertujuan untuk memperoleh informasi yang relevan dengan tujuan penelitian, dan memperoleh informasi yang memiliki validitas dan reliabilitas tinggi. Data yang dikumpulkan meliputi data kuantitatif dan data kualitatif. Data yang telah dikumpul ditabulasi dan dianalisis kemudian dilakukan pengkategorian sesuai dengan skor yang dihasilkan pada masingmasing hasil pengukurannya. Data kuantitatif diolah dan dianalisis dengan menggunakan statistik deskriptif dan inferensial. Analisis statistik deskriptif dilakukan untuk mengidentifikasi dukungan penyuluhan, dukungan lingkungan eksternal. Analisis statistik deskriptif dilakukan dengan memberikan skor pada setiap data kemudian ditabulasi, menggolongkan dan menghitung jawaban berdasarkan frekuensi serta persentase berdasarkan kategori jawaban. Keseluruhan data diolah dengan menggunakan tabulasi distribusi frekuensi. Analisis statistik inferensial diukur dengan menggunakan analisis pendekatan Partial Least Square (PLS). Dalam pendekatan PLS terdapat variabel laten dan indikator manifestasi. Untuk variabel laten karakteristik peternak (X1), dukungan penyuluhan (X2) dan dukungan lingkungan eksternal (X3) adalah variabel laten exogenous (variabel bebas), sedangkan variabel laten kompetensi peternak (Y1) dan keberlanjutan usaha (Y2) adalah variabel laten endogenous (variabel terikat). Adapun model konseptual penelitian disajikan pada Gambar 1.

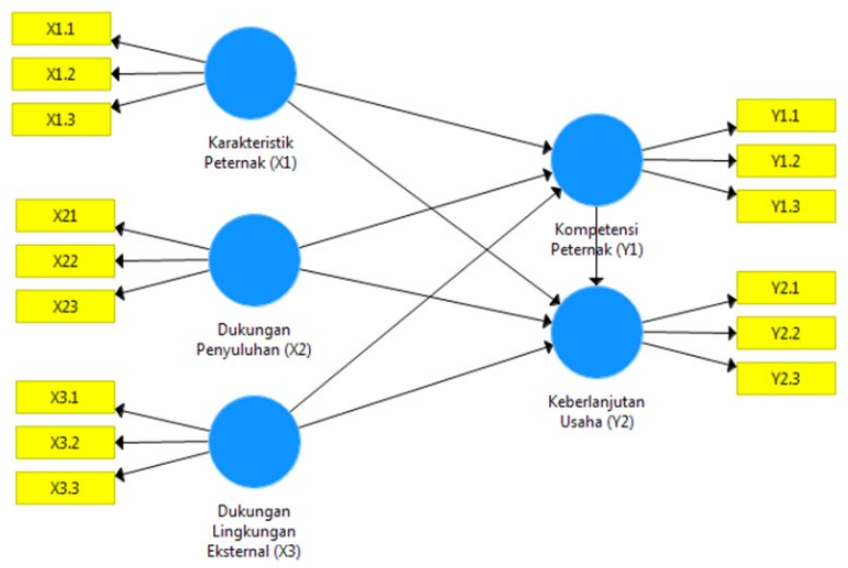

Gambar 1 Model Konseptual Penelitian

Keterangan:

Variabel Laten Exogenous

$\mathrm{X}_{1} \quad=$ Karakteristik Peternak

Indikator Manifestasi:

$\mathrm{X} 1 \_1=$ Umur Peternak

$\mathrm{X} 2{ }^{-1}=$ Ketepatan Metode

$\mathrm{X} 1{ }^{-} 2=$ Pendidikan Formal

$\mathrm{X} 1 \_3=$ Pengalaman Beternak

$\mathrm{X}_{3}=$ Dukungan Lingkungan Eksternal

Indikator Manifestasi:

X3 $1=$ Kebijakan Pemerintah

X3_2 Kelembagaan Pasar dan Modal
X2= Dukungan Penyuluhan Indikator Manifestasi

$\mathrm{X} 22=$ Kesesuaian Materi $\mathrm{X} 2 \_3=$ Kompetensi Penyuluh 


\section{X3_3 = Kelembagaan Sarana Produksi}

\section{Variabel Laten Endogenous}

Y1 = Kompetensi Peternak

Usaha

Indikator Manifestasi:

Y1 $1=$ Kemampuan Pengambilan Keputusan Proses Produksi

Y1 2 = Kemampuan Menjalin Kerjasama

Y1_3 = Kemampuan Mengakses Pasar dan Modal

\section{$\mathrm{Y} 2=\quad$ Keberlanjutan \\ Indikator Manifestasi \\ Y2 1 = Ekonomi \\ Y2 2 = Lingkungan \\ Y2_3 = Sosial}

\section{Hasil dan Pembahasan}

\subsection{Karakteristik Peternak}

Karakteristik peternak merupakan sifat-sifat atau ciri-ciri yang dimiliki oleh peternak yang melekat pada dirinya. Ciri-ciri yang dimaksud adalah bagian dari diri peternak yang terbawa sejak lahir serta merupakan proses interaksi dengan lingkungan. Karakteristik peternak yang dimaksud dalam penelitian ini adalah (1) umur, pendidikan dan pengalaman. Karakteristik peternak sapi potong berdasarkan umur, pendidikan dan pengalaman di Desa Oebkim disajikan pada Tabel 1 .

Tabel 1 Karakteristik Peternak Sapi Potong di Desa Oebkim Tahun 2020

\begin{tabular}{lcc}
\hline Kategori & Jumlah & Presentase (\%) \\
\hline Umur (tahun) & 11 & 33.33 \\
Muda $(25-35)$ & 13 & 39.40 \\
Sedang $(36-45)$ & 13 & 18.18 \\
Tua $(46-55)$ & 3 & 9.10 \\
Sangat Tua $(56-65)$ & & \\
Pendidikan Formal & 0 & 0 \\
Tidak pernah bersekolah & 3 & 9.1. \\
Tamat SD & 12 & 36.36 \\
Tamat SMP & 16 & 48.48 \\
Tamat SMA & 2 & 6.06 \\
Tamat PT & & \\
Pengalaman beternak (tahun) & 0 & 0 \\
Sangat Baru (<2 ) & 13 & 39.39 \\
Baru (2 - 5 ) & 15 & 45.45 \\
Sedang ( 6 - 10 ) & 5 & 15.55 \\
Lama ( $>$ 10 ) & &
\end{tabular}

Umur peternak menjadi suatu faktor yang mempengaruhi kemampuan fisik peternak dalam mengelola usaha peternakan sapi potong. Hal ini sesuai dengan hasil penelitian Suwarta (2012) yang menunjukkan bahwa semakin bertambah umur peternak mengakibatkan produktivitas usaha ternak semakin menurun. Peternak yang mempunyai tingkat pendidikan rendah kondisi usahanya relatif sama dengan peternak yang mempunyai tingkat pendidikan yang tinggi. Dalam prakteknya hubungan antara tingkat pendidikan dan tingkat adopsi adalah berjalan secara tidak langsung, kecuali bagi mereka yang belajar secara spesifik tentang inovasi baru tersebut di sekolah. Pengalaman usaha tidak menunjukkan bahwa semakin lama berusaha maka semakin tinggi pengetahuan yang dimiliki mengenai usaha peternakan sapi potong. Hasil Penelitian Hermawan et al. (2017) menunjukkan pengalaman usaha secara tidak langsung menunjukkan kemampuan pembudidaya yang baik dalam menjalankan usahanya.

\subsection{Dukungan Penyuluhan}

Penyuluhan merupakan salah satu proses pendidikan non formal yang dapat mendukung terjadinya perubahan perilaku peternak. Perubahan perilaku peternak memerlukan waktu yang lama, sehingga penyuluhan yang berkelanjutan penting sekali dilaksanakan Keefektifan pelaksanaan kegiatan penyuluhan oleh tiga kelembagaan penyuluhan yaitu penyuluh pemerintah, penyuluh swasta dan penyuluhan swadaya harus didukung oleh metode dan materi yang sesuai, penyuluh yang kompeten dan ketersediaan sarana dan prasarana. Tingkat dukungan penyuluhan terhadap peternak di Desa Oebkim disajikan pada Tabel 2.

Dukungan penyuluhan terhadap peternakan sapi potong di Desa Oebkim dominan tidak sesuai dengan kebutuhan peternak. Hal ini dirasakan peternak terkait peran lembaga penyuluh sangat minim dalam mendampingi mereka untuk mengembangkan usaha peternakan sapi potong. Pada umumnya peternak jarang mendapatkan penyuluhan. Sebagian peternak mengaku umumnya penyuluh telah menggunakan metode yang mudah dipahami ketika dilakukan kegiatan penyuluhan dan telah sesuai dengan kompetensinya. Peternak di Oebkim sangat membutuhkan layanan penyuluhan dan penyuluh yang bisa mendampingi mereka agar mampu meningkatkan kinerja usaha peternakannya.

Slamet (2003) menyatakan bahwa pendidikan yang diberikan kepada masyarakat adalah pendidikan nonformal atau penyuluhan yang berperan memberdayakan sasaran. Penyuluhan kepada peternak belum dilakukan secara terencana dan terjadwal. Peran penyuluh dalam pengorganisasian perternak belum dilakukan sehingga peternak di Desa Oebkim mengelola usahanya secara sendiri tanpa berkelompok. Terkait program pembinaan peternak belum dirasakan oleh peternak sapi potong di Desa Oebkim.

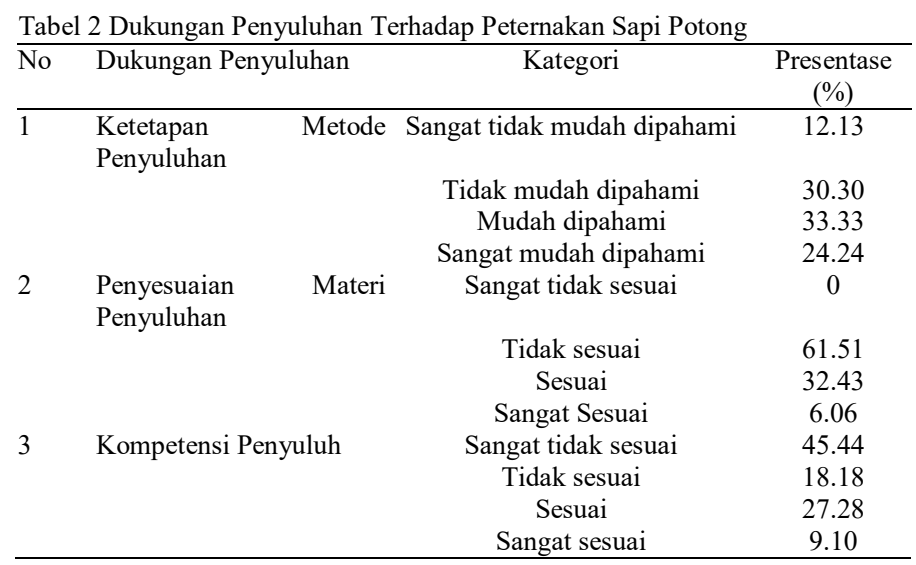

\subsection{Dukungan Lingkungan Eksternal}

Lingkungan eksternal adalah faktor-faktor yang berada diluar diri peternak yang diduga berhubungan dengan kompetensi peternak sapi potong $\mathrm{d}$ Desa Oebkim . Dukungan lingkungan diamati dengan indikator kebijakan pemerintah, kelembagaan pasar dan modal dan kelembagaan sarana dan prasarana. Hasil penelitian menunjukkan dukungan lingkungan eksternal dengan indikator kebijakan pemerintah sebesar 69.70 persen tidak sesuai dengan kebutuhan peternak dalam mengembangkan usaha peternakan di Oebkim.

Peternak menilai kebijakan pemerintah belum mampu menjawab sebagian besar kebutuhan petani terkait bantuan bibit unggul, mesin pencacah pakan yang sangat dibutuhkan oleh peternak sapi potong. Rendahnya peran dan ketersediaan kebijakan pemerintah yang mendorong usaha ternak serta tidak tersedianya lembaga pendukung usaha ternak yang memadai menyebabkan kecenderungan rendahnya tingkat kompetensi peternak. Padahal menurut Ife dan Tesoriero (2008) strategi yang dapat dilakukan untuk mencapai peningkatan kompetensi adalah melalui kebijakan dan perencanaan, aksi sosial dan politik, pendidikan dan penyadaran.

Dariah (2009) menyatakan pemberdayaan masyarakat merupakan salah satu upaya untuk mempersiapkan masyarakat dengan memperkuat kelembagaan masyarakat agar mampu mewujudkan kemajuan, kemandirian, dan kesejahteraan dalam suasana keadilan sosial berkelanjutan. Dukungan lingkungan eksternal yang tidak sesuai juga didasarkan pada kondisi pasar ternak yang belum mampu diakses oleh peternak. Pada umumnya menjual ternak dan membeli ternak bakalan dari pedagang pengumpul (tengkulak). Peran pedagang pengumpul sangat kuat dalam pemasaran ternak sapi potong oleh peternak di Desa Oebkim. Peternak mengakui belum ada lembaga permodalan yang mau memberikan modal dalam pengembangan usahanya. Tingkat dukungan lingkungan eksternal disajikan pada Tabel 3.

Tabel 3 Tingkat Dukungan Lingkungan Eksternal

\begin{tabular}{|c|c|c|c|}
\hline & Dukungan Lingkungan & Kategori & Persentase \\
\hline \multirow[t]{4}{*}{1} & Kebijakan Pemerintah & Sangat tidak sesuai & 0 \\
\hline & & Tidak sesuai & 69.70 \\
\hline & & Sesuai & 30.30 \\
\hline & & Sangat sesuai & 0 \\
\hline \multirow[t]{4}{*}{2} & Kelembagaan & Sangat tidak sesuai & 0 \\
\hline & & Tidak sesuai & 32.43 \\
\hline & & sesuai & 61.51 \\
\hline & & Sangat sesusi & 6.06 \\
\hline \multirow[t]{4}{*}{3} & Kelembagaan Sarana & Sangat tidak sesuai & 0 \\
\hline & & Tidak Sesuai & 45.45 \\
\hline & & Sesuai & 42.42 \\
\hline & & Sangat sesuai & 45.45 \\
\hline
\end{tabular}

\subsection{Kompetensi Peternak}

Kompetensi peternak diukur berdasarkan kemampuan peternak dalam pengambilan keputusan pengadaan sarana produksi, kemampuan menjalin kerjasama dan kemampuan dalam pemasaran. Hasil penelitian menunjukkan bahwa tingkat kompetensi peternak sebagian besar berada dalam kategori sangat tidak kompeten dan tidak kompeten. Peternak sapi potong sebanyak 39.39 persen telah kompeten dalam menentukan keputusan dalam mengelola usaha peternakan sapi potong seperti menentukan bibit ternak dan pakan konsentrat apa yang akan diberikan ke ternak tanpa ada intervensi pihak lain. Adapun tingkat kompetensi peternak sapi potong disajikan pada Tabel 4.

Sebagian besar peternak sangat tidak berdaya dalam menjalin kerjasama hal ini disebabkan kondisi peternak yang tidak mampu menjalin kerjasama dengan berbagai pihak seperti UPT Puskeswan atau Dinas Peternakan, dalam mengembangkan usaha peternakannya. Kemampuan peternak dalam mengakses pasar juga tergolong tidak berdaya. Hal ini disebabkan umumnya peternak tidak menggunakan fasilitas pasar ternak dalam menjual ternak serta cenderung lemah dalam menetapkan harga. Peran pedagang pengumpul 
menjadi dominan dalam bisnis peternakan sapi potong di Desa Oebkim serta memiliki kekuatan dalam menentukan harga ternak sapi potong. Kelembagaan Pasar dan Modal menjadi satu - satunya akses utama yang bisa dimanfaatkan sehingga usaha peternakan sapi potong bisa dipertahankan oleh peternak. Para peternak umumnya belum dapat menunjukkan kompetensinya terutama dalam kemampuan menjalin kerjasama. Rendahnya kemampuan peternak dalam pengambilan keputusan proses produksi terlihat dari masih minimnya peternak di dalam melakukan perincian terhadap usahanya dan penyusunan prioritas dalam pengembangan usaha.

Tabel 4. Tingkat Kompetensi Peternak Sapi Potong di Desa Oebkim

\begin{tabular}{llll}
\hline No & Dukungan Lingkungan & Kategori & Persentase \\
\hline & Kemampuan Dalam & & 6.36 \\
1 & $\begin{array}{l}\text { Pengambilan Keputusan Proses } \\
\text { Produksi }\end{array}$ & Sangat tidak mampu & \\
& & Tidak mampu & 39.39 \\
& & Mampu & 18.18 \\
& \multirow{2}{*}{ Kemampuan Menjalin Kerjasama } & Sangat mampu & 6.07 \\
& Sangat tidak mampu & 7.57 \\
& Tidak mampu & 30.30 \\
& Mampu & 12.13 \\
& \multirow{2}{*}{ Kemampuan Mengakses Pasar } & Sangat mampu & 0 \\
& dan Modal & Sangat tidak mampu & 21.22 \\
& & \\
& & Tidak mampu & 8.48 \\
& Mampu & 15.15 \\
& Sangat mampu & 15.15 \\
\hline
\end{tabular}

\subsection{Keberlanjutan Usaha}

Keberlanjutan usaha merupakan adanya kemampuan seseorang yang menjalankan usaha secara terus menerus dengan tetap memperhatikan sumber daya alam yang ada di lingkungannya dan sumber daya manusia yang dimiliki agar dapat menghadapi berbagai resiko dan perubahan. Keberlanjutan usaha meliputi aspek skala usaha, keterjaminan pasar dan tingkat produksi. Adapun tingkat keberlanjutan usaha disajikan pada Tabel 5 .

Tabel 5 Tingkat Keberkanjutan Usaha Peternakan Sapi Potong

\begin{tabular}{cccc}
\hline No & Variabel & Kategori & Persentase \\
\hline 1 & Lingkungan & Sangat rendah & 9.10 \\
& & Rendah & 45.45 \\
& & Sedang & 30.30 \\
& & Tinggi & 15.15 \\
2 & \multirow{3}{*}{ Ekonomi } & Sangat rendah & 6.06 \\
& & Rendah & 6.06 \\
& & Sedang & 30.30 \\
3 & Sosial & Tinggi & 54.54 \\
& & Sangat rendah & 9.10 \\
& & Rendah & 12.12 \\
& & Sedang & 30.30 \\
& & Tinggi & 48.48 \\
\hline
\end{tabular}

Aspek sosial menjadi hal yang perlu diprioritaskan karena usaha tidak akan berkembang jika kohesivitas dan kerukunan antar masyarakat bermasalah. Pada sisi ekonomi keberlanjutan usaha mempunyai potensi yang layak untuk dikembangkan karena keuntungan yang diperoleh peternak meningkat bersamaan dengan meningkatnya produktivitas. Meskipun demikian, pada aspek lingkungan perlu untuk diperhatikan sebab terdapat daya dukung rendah. Usaha peternakan harus memperhatikan letak lokasi perkandangan dan penanganan kotoran ternak sehingga tidak menimbulkan bau tidak sedap.

\subsection{Faktor Berpengaruh Terhadap Kompetensi Peternak}

Evaluasi model pengukuran dan struktural yang dilakukan terhadap hasil analisis PLS menunjukkan bahwa faktor-faktor yang mempengaruhi keberdayaan peternak di Desa Oebkim adalah dukungan lingkungan eksternal. Dukungan eksternal memiliki pengaruh lebih besar daripada dukungan penyuluhan. Persamaan model struktural faktor yang mempengaruhi kompetensi peternak sapi potong adalah: $\mathrm{Y} 1=0.450 \mathrm{X} 3+0.77$ Nilai $\mathrm{R}^{2}$ sebesar 0.238 menunjukkan bahwa 23.8 persen kompetensi peternak sapi potong dipengaruhi oleh faktor-faktor yang diteliti dalam penelitian ini sedangkan 76.2 persen dipengaruhi oleh faktor lain di luar penelitian. Model pengukuran (outer model) disajikan pada Gambar 2.

Adapun model struktural (inner model) karakteristik peternak, dukungan penyuluhan dan dukungan lingkungan eksternal terhadap kompetensi peternak disajikan pada Tabel 6 .

Kompetensi peternak direfleksikan oleh kemampuan dalam pemasaran $\left(\mathrm{Y}_{1.3)}\right.$. Hal ini didasarkan unsur kompetensi tersebut memiliki factor loading di atas 0.7 sedangkan unsur kompetensi lainnya seperti kemampuan pengambilan keputusan proses produksi dan kemampuan menjalin kerjasama memiliki nilai factor loading dibawah 0.7 sehingga tidak mampu merefleksikan tingkat kompetensi peternak. Hal ini menunjukkan bahwa kemampuan peternak dalam merencanakan dan mengorganisir usaha peternakan sebagian besar berada dalam keadaan tidak berdaya. Hasil penelitian Yasmin dan Ikemoto (2015) menunjukkan program pemberdayaan mampu meningkatkan kepercayaan diri dan memiliki kekuatan pengambilan keputusan dalam mengelola usaha peternakan.

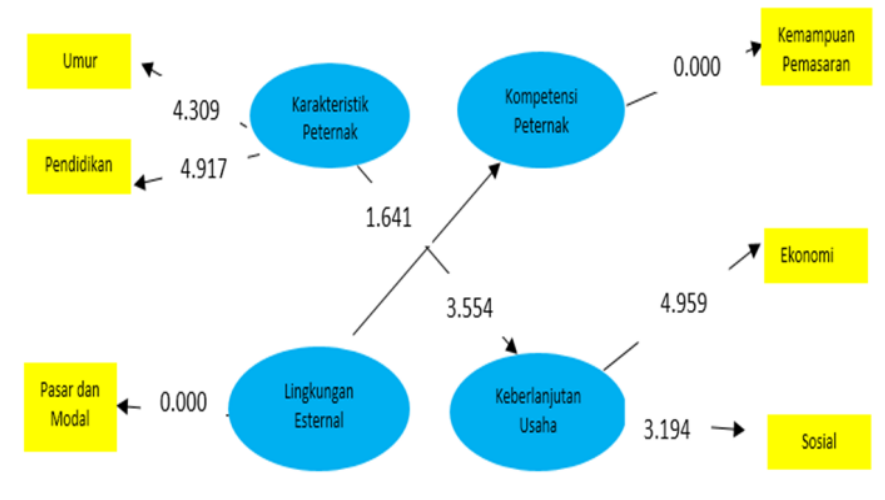

Gambar 2 Model Pengukuran

Dukungan penyuluhan tidak berpengaruh secara signifikan terhadap kompetensi peternak. Dukungan penyuluhan direfleksikan oleh ketepatan metode penyuluhan $\left(\mathrm{X}_{2.1}\right)$. Dukungan penyuluhan tidak berpengaruh terhadap kompetensi disebabkan jarangnya pelayanan penyuluhan dan pendampingan oleh penyuluh terhadap peternak di Desa Oebkim. Justru kehadiran penyuluh diharapkan sehingga dukungan penyuluhan seharusnya berpengaruh terhadap kompetensi peternak. Hal ini sesuai penelitian Satria (2009) bahwa aktivitas pemberdayaan tidak terlepas dari fungsi-fungsi penyuluhan, karena prinsip prinsip pemberdayaan sama saja dengan prinsip-prinsip penyuluhan yang bertujuan pada to help them help themselves.

Kompetensi penyuluh juga belum menginterventarisis kebutuhan peternak. Pada hal kompetensi dapat digunakan untuk memprediksi bahwa seseorang akan mampu menyelesaikan pekerjaan dengan baik atau tidak (Malta, 2011). Hasil penelitian Anwas (2011) menunjukkan kompetensi penyuluh harus dilandasi oleh pengetahuan, keterampilan, dan didukung oleh sikap dalam melaksanakan tugasnya untuk memberdayakan petani.

Berdasarkan observasi di lapangan, rendahnya kompetensi peternak tidak bisa dilepaskan dari minimnya peran penyuluh dalam mendampingi dan memberdayakan perternak dalam mengakses kelembagaan pemasaran dan modal guna mendukung usaha peternakan sapi potong di Desa Oebkim. Kelembagaan pasar dan modal belum sepenuhnya berfungsi pada usaha peternakan sapi potong. Sebagian peternak masih kesulitan dalam mengakses modal dan kredit usaha sehingga peternak terbatas dalam menambah skala usahanya. Hasil penelitian Yunasaf dan Basita (2007) menunjukkan peran penyuluh dan fungsi koperasi sangat penting dalam meningkatkan kompetensi peternak.

Hasil penelitian Kingu dan Ndiege (2018) menunjukkan koperasi memiliki manfaat bagi peternak sapi perah skala kecil dalam hal efisiensi biaya produksi dan efisiensi pemasaran. Kondisi sosial ekonomi peternak di Desa Oebkim menunjukkan pengaruh pedagang pengumpul dalam proses jua beli ternak masih tinggi sehingga sebagian peternak masih menjual hasil usahanya dengan harga dibawah harga standar. Meskipun demikian pengaruh kelembagaan pasar dan modal telah berpengaruh terhadap kompetensi dibandingkan karakteristik peternak dan dukungan penyuluhan. Hal ini cukup beralasan karena sejauh ini yang secara langsung dan kontiniu berhubungan dengan peternak adalah lembaga pasar dan modal.

Tabel 6 Nilai Signifikansi Peubah Laten Kompetensi Peternak

\begin{tabular}{clccc}
\hline No & $\begin{array}{l}\text { Matriks pengaruh masing- } \\
\text { masing peubah laten }\end{array}$ & $\begin{array}{l}\text { Koefisien } \\
\text { Alur }\end{array}$ & $\begin{array}{c}\text { T- } \\
\text { Hitung }\end{array}$ & Signifikansi \\
\hline 1 & $\begin{array}{l}\text { Karakteristik Peternak }=> \\
\text { Kompetensi Peternak }\end{array}$ & 0.124 & 0.665 & Tidak signifikan \\
2 & $\begin{array}{l}\text { Dukungan Penyuluhan }=> \\
\text { Kompetensi Peternak } \\
\text { Lingkungan Eksternal }=> \\
\text { Kompetensi Peternak }\end{array}$ & -0.100 & 0.668 & Tidak signifikan \\
\hline
\end{tabular}

\subsection{Faktor Berpengaruh Terhadap Keberlanjutan}

Evaluasi model pengukuran dan struktural yang dilakukan terhadap hasil analisis PLS menunjukkan bahwa faktor-faktor yang mempengaruhi keberlanjutan usaha di Desa Oebkim adalah karakteristik peternak. Karakteristik peternak memiliki pengaruh dibandingkan dukungan penyuluhan dan dukungan lingkungan eksternal. Persamaan model struktura faktor yang mempengaruhi keberlanjutan usaha peternakan sapi potong adalah: $\mathrm{Y} 2=-0.392 \mathrm{X} 1+0.80$. Nilai $\mathrm{R}^{2}$ sebesar 0.207 menunjukkan bahwa 20.7 persen keberlanjutan usaha peternak sapi potong dipengaruhi oleh faktor-faktor yang diteliti dalam penelitian ini sedangkan 79.3 persen dipengaruhi oleh faktor lain di luar penelitian ini. Adapun model struktural (inner model) karakteristik peternak, dukungan penyuluhan dan dukungan lingkungan eksternal terhadap keberlanjutan usaha disajikan pada Tabel 7. 
Tabel 7 Nilai Signifikansi Peubah Laten Keberlanjutan Usaha

\begin{tabular}{clccc}
\hline No & $\begin{array}{l}\text { Matriks pengaruh masing- } \\
\text { masing peubah laten }\end{array}$ & $\begin{array}{c}\text { Koefisien } \\
\text { jalur }\end{array}$ & $\begin{array}{c}\text { T- } \\
\text { Hitung }\end{array}$ & Signifikansi \\
\hline 1 & $\begin{array}{l}\text { Karakteristik Peternak }=> \\
\text { Keberlanjutan }\end{array}$ & -0.392 & 1.641 & Signifikan \\
2 & $\begin{array}{l}\text { Dukungan Penyuluhan } \\
\text { => Keberlanjutan }\end{array}$ & 0.131 & 0.791 & $\begin{array}{c}\text { Tidak } \\
\text { signifikan } \\
\text { Tidak } \\
\text { signifikan }\end{array}$ \\
\hline
\end{tabular}

Hasil analisis PLS menunjukkan bahwa karakteristik peternak memiliki berpengaruh negatif terhadap keberlanjutan usaha. Semakin tinggi karakteritistik peternak maka akan mempengaruhi penurunan keberlanjutan usaha. Hal ini dinilai dipengaruhi umur peternak, apabila umur peternak semakin bertambah maka akan mempengaruhi penurunan kemampuan fisik dan pikiran peternak dalam meningkatkan skala usaha pemeliharaan dan mengolah kotoran agar tidak mencemari lingkungan dan mengganggu kehidupan sosial masyarakat.

Dukungan penyuluhan tidak berpengaruh terhadap keberlanjutan usaha. Berbeda dengan hal tersebut, Yunasaf et al. (2008) dan Humaidi, et al. (2017) menyatakan kehadiran penyuluhan dan inovasi sejatinya mampu meningkatkan kompetensi peternak dalam mendukung keberlanjutan usaha. Dukungan lingkungan eksternal juga ternyata tidak berpengaruh terhadap keberlanjutan usaha peternakan sapi potong.

Hasil factor loading menunjukkan hanya dua indikator yang merefleksikan keberlanjutan usaha yaitu pada indikator ekonomi dan sosial, sedangkan satu indikator lainnya harus dikeluarkan dari model karena nilainya dibawah factor loading 0.7 yaitu aspek lingkungan 0.249 . Keberlanjutan pada aspek ekonomi memiliki pengaruh karena memang usaha peternakan sapi potong difokuskan pada aspek peningkatan produktivitas. Tujuan yang ingin dicapai hanya pada peningkatan keuntungan semata sehingga aktivitas-aktivitas difokuskan pada peningkatan skala usaha pemeliharaan dan peningkatan pendapatan keluarga. Aspek sosial merefleksikan keberlanjutan usaha karena memang kehadiran usaha peternakan di lingkungan sosial masyarakat tidak pernah menjadi ancaman dan masalah dengan usaha masyarakat yang lain bahkan di masa yang akan datang.

Pada aspek lingkungan tidak merefleksikan keberlanjutan usaha. Peternak jarang sekali membahas dan melakukan kegiatan bersama tentang pengaruh peternakan dengan lingkungan, bahkan lokasi perkadangan yang dekat dengan pemukiman penduduk dimungkinkan mengganggu lingkungan namun masyarakat pada umumnya memaklumi bau yang tidak sedap karena usaha lokasi perkandangan sapi potong tersebut.

\subsection{Pengaruh Kompetensi Peternak Terhadap Keberlanjutan Usaha}

Kompetensi peternak memiliki hubungan secara positif dan langsung, namun tidak berpengaruh terhadap keberlanjutan usaha peternakan sapi potong. Analisis Partial Least Square (PLS) dilakukan untuk mengetahui pengaruh kompetensi terhadap keberlanjutan usaha peternakan sapi potong di Desa Oebkim. Adapun model struktural (inner model) kompetensi peternak terhadap keberlanjutan usaha disajikan pada Tabel 8.

Tabel 8 Nilai Signifikansi Peubah Laten Keberlanjutan Usaha

\begin{tabular}{|c|c|c|c|c|c|}
\hline $\begin{array}{l}\mathrm{N} \\
\mathrm{o}\end{array}$ & $\begin{array}{l}\text { Matriks pengaruh masing- } \\
\text { masing peubah laten }\end{array}$ & & $\begin{array}{l}\text { Koefisie } \\
\mathrm{n} \text { jalur }\end{array}$ & $\begin{array}{c}\text { T- } \\
\text { Hitung }\end{array}$ & Signifikansi \\
\hline 1 & $\begin{array}{l}\text { Kompetensi Peternak } \\
\text { Keberlanjutan }\end{array}$ & & -0.002 & 0.008 & $\begin{array}{c}\text { Tidak } \\
\text { signifikan }\end{array}$ \\
\hline
\end{tabular}

Dominasi peternak dalam kategori tidak berdaya dinilai menjadi penyebab tingkat kompetensi tidak berpengaruh pada keberlanjutan usaha. Ketidakberdayaan peternak dalam menjalin kerjasama dengan berbagai pihak tentu tidak menjadikan usaha peternakan sapi potong cenderung stagna bahkan menurun dari sisi produktivitas. Ketidakberdayaan peternak dalam mengakses modal juga menyebabkan kepemilikan skala usaha tidak ekonomis yang nantinya akan mempengaruhi keberlanjutan usaha. Dengan demikian perlu peningkatan kualitas dan kuantitas elemen penyuluhan guna meningkatkan kompetensi peternak agar mampu mendorong keberlanjutan usaha. Sulistiyani (2004) menyebutkan pemberdayaan sangat penting dalam mendukung keberlanjutan usaha sebagai suatu proses pemberian daya atau kekuatan dari pihak yang memiliki daya kepada pihak yang kurang atau belum berdaya.

\section{Simpulan}

Berdasarkan hasil penelitian, maka disimpulkan bahwa karakteristik umur peternak di Desa Oebkim bervariasi dengan didominasi peternak umur sedang sebesar 39.40 persen. Tingkat pendidikan peternak didominasi peternak berpendidikan SMA. Pengalaman beternak sapi potong didominasi pengalaman sedang. Dukungan penyuluhan dengan indikator ketepatan metode memiliki nilai paling besar di kategori mudah dipahami. Indikator kesesuaian materi penyuluhan didominasi dengan kategori tidak sesuai. Faktor yang mempengaruhi kompetensi peternak di Desa Oebkim adalah dukungan lingkungan eksternal. Faktor yang mempengaruhi keberlanjutan usaha peternakan sapi potong di Desa Oebkim adalah karakteristik peternak. Kompetensi peternak tidak berpengaruh terhadap keberlanjutan usaha peternakan sapi potong.

\section{Pustaka}

Anwas, O. M. 2011. Membangun Media Massa Publik dalam Menanamkan Pendidikan Karakter. Jurnal Pendidikan Dan Kebudayaan, 17(6), 680690.

Dariah RA. 2009. Peran Perguruan Tinggi dalam Aplikasi Variasi Model Pemberdayaan Masyarakat Desa di Jawa Barat. Jurnal Mimbar. 25(2): $143-151$.

Hasnawati, Fariyanti A, Mulatsih S. 2019. Peranan Kelompok Peternak Dalam Menunjang Keberhasilan Usaha Sapi Potong Di Kabupaten Boalemo. Jurnal Manajemen Pembangunan https://doi.org/10.29244/jurnal_mpd.v6i2.25107

Hermawan A, Amanah S, Fatchiya A. 2017. Partisipasi Pembudidaya Ikan dalam Kelompok Usaha Akuakultur di Kabupaten Tasikmalaya, Jawa Barat. Jurnal Penyuluhan. 13(1): 1-13.

Humaidi Edy, Putri Suci Asriani, B. S. P. (2017). Strategi Keberlanjutan Agribisnis Beras Organik Di Kelompok Tani Handayani Kecamatan Bts Ulu Kabupaten Musi Rawas. Unib Schoolar Repository. Retrieved from http://repository.unib.ac.id/id/eprint/15023

Ife J, Tesoriero F. 2008. Alternatif Mengembangan masyarakat di Era Globalisasi: Cetakan 1. Yogyakarta : Pustaka Pelajar.

Kingu D, Ndiege BO. 2018. Empowering Small Scale Dairy Farmers Through The Cooperatives Model. Journal of Co-operative and Business Studies (JCBS) 2 (1)

Malta 2011. Faktor-faktor yang Berhubungan dengan Kinerja Petani Jagung di lahan Gambut. Jurnal Mimbar. 27(1):67-78.

Mauludin MA, Winaryanto, Alim S. 2012. Peran Kelompok Dalam Mengembangkan Keberdayaan Peternak Sapi Potong. Jurnal Ilmu Ternak 12 (1):1-8

Muharastri Y, Pambudy R, Priatna BW. 2015. Hubungan Karakteristik Wirausaha Dengan Kompetensi Kewirausahaan Peternak Sapi Perah di Kabupaten Bogor. JSEP 8 (1): 25-36.

Satria A. 2009. Dinamika Modernisasi Perikanan: Formasi Sosial dan Mobilitas Nelayan. Bandung: Humaniora Utama Press.

Slamet. 2003. Pembangunan Masyarakat Berwawasan Partisipasi. Surakarta: Sebelas Maret University Press.

Sulistiyani, Ambar, Teguh. 2004, Kemitraan dan Model-Model Pemberdayaan. Yogyakarta: Gava Media.

Suwarta, Irham, Hartono S. 2012. Struktur Biaya dan Pendapatan Usaha Ternak Ayam Broiler di Kabupaten Sleman. Agrika 6(1): 66-85.

Yasmin S, Ikemoto Y. 2015. Women's Empowerment through Small-Scale Dairy Farming in Selected Areas of Bangladesh. Asian Social Science. $11: 290$

Yunasaf U, Ginting B. 2007. Faktor-Faktor Yang Mempengaruhi Keberdayaan Peternak Sapi Perah Di Kabupaten Bandung. Jurnal Ilmu Sosial Humaniora Vol $\quad 9 \quad$ (3) doi:https://doi.org/10.24198/sosiohumaniora.v9i3. 5569

Yunasaf U, Ginting B, Slamet M, Tjitropranoto P. 2008. Peran Kelompok Peternak Dalam Mengembangkan Keberdayaan Peternak Sapi Perah (Kasus Di Kabupaten Bandung). Jurnal Penyuluhan 4 (2). 